\title{
Polymorphisms of the Toll-Like Receptor-2 Gene in Patients with Leprosy and Their Healthy Contacts
}

\author{
Luana Nepomuceno Gondim Costa Lima1,2,3* (), Letícia Siqueira Moura4 (i), \\ Jasna Leticia Pinto Paz², Maria do Perpétuo Socorro Amador Silvestre1, \\ Daniele Melo Sardinha ${ }^{3}$ (D) Letícia Diogo de Oliveira Moura5 (), \\ Karla Valéria Batista Lima1,2 \\ ${ }^{1}$ Bacteriology and Mycology Section, Instituto Evandro Chagas, Ananindeua, PA, Brazil \\ ${ }^{2}$ Postgraduate Program in Parasitic Biology in the Amazon at the Universidade do Estado do Pará, Belém, PA, Brazil \\ ${ }^{3}$ Postgraduate Program in Epidemiology and Health Surveillance (PPGEVS), Instituto Evandro Chagas (IEC), Ananindeua, PA, \\ Brazil \\ ${ }^{4}$ Graduate in Natural Sciences, Universidade do Estado do Pará, Belém, PA, Brazil \\ ${ }^{5}$ Postgraduate Program in Nursing, Universidade Federal do Pará, Belem, PA, Brazil \\ Email: ^luanalima@iec.gov.br, letysiq@outlook.com, jasnapaz@yahoo.com.br, socorroamador@iec.gov.br, \\ danielle-vianna20@hotmail.com, le_moura_@hotmail.com, karlalima@iec.gov.br
}

How to cite this paper: Lima, L.N.G.C., Moura, L.S., Paz, J.L.P., Silvestre, M. do P.S.A., Sardinha, D.M., Moura, L.D. de O. and Lima, K.V.B. (2020) Polymorphisms of the Toll-Like Receptor-2 Gene in Patients with Leprosy and Their Healthy Contacts. Open Journal of Immunology, 10, 37-46. https://doi.org/10.4236/oji.2020.103004

Received: May 21, 2020

Accepted: August 15, 2020

Published: August 18, 2020

Copyright $\odot 2020$ by author(s) and Scientific Research Publishing Inc. This work is licensed under the Creative Commons Attribution International License (CC BY 4.0).

http://creativecommons.org/licenses/by/4.0/

\begin{abstract}
Leprosy is an immunopathology caused by M. leprae; its evolution depends on immunological and genetic aspects of the host. The objective was verifying the relationship between SNPs 2029 and 2258 of the TLR-2 gene and leprosy. Blood samples from 127 individuals were analyzed: 45 patients, being 34 multibacillary (MB) and 11 paucibacillary (PB) and 82 contacts, in the municipalities of the State of Pará-Brazil. SNPs 2029 and 2258 of the TLR-2 gene were genotyped by sequencing on the ABI 3130 Genetic Analyzer (Applied Biosystems), analyzed using Fisher's exact test. Distribution of SNP 2029 genotypes: all $\mathrm{MB}$ individuals presented the $\mathrm{C} / \mathrm{C}$ genotype and the mutant $(\mathrm{C} / \mathrm{T})$ genotype was observed in contacts and $\mathrm{PB}$. Alleles: all $\mathrm{MB}$ individuals presented only $\mathrm{C}$ allele and the mutant allele (T) was observed in contacts and PB. SNP 2258 genotypes: 79 contacts had G/G genotype and only 3 had G/A genotype, the $\mathrm{MB}$ group had only $\mathrm{G} / \mathrm{G}$ genotype and the $\mathrm{PB}$ group was predominant G/G, with only $1 \mathrm{G} / \mathrm{A}$ genotype. Alleles: all $\mathrm{MB}$ individuals had allele $\mathrm{G}$ and the mutant allele (A) was observed in contacts and $\mathrm{PB}$. The association between the SNPs and the susceptibility or protection to leprosy was not observed.
\end{abstract}

\section{Keywords}

Polymorphism, Toll-Like Receptors, Leprosy 


\section{Introduction}

Leprosy is an immunopathology caused by Mycobacterium leprae and the evolution of the infection depends on the host's immunological and genetic factors, being the North region considered the area with the highest leprosy endemicity in Brazil [1] [2].

Its tuberculoid (HT) (paucibacillary) form corresponds to high resistance to infection by $M$. leprae, being related to the Th1 cellular immune response. At the other pole, it is the form of high susceptibility, lepromatous leprosy (HV) (multibacillary), characterized by the deficiency of Th1 cellular immune response, consequently, excessive bacillary multiplication and spread of infection. Among these polar forms are the dimorphic forms of the disease. In HV, high concentrations of specific $M$. leprae antibodies are found in serum, such as anti-PGL1 (phenolic glycolipid-1), associated with exacerbation of the Th2 response [3] [4] [5].

The innate immune response is the first line of defense against $M$. leprae, being a crucial step for the development of the response against the bacillus, since it has essential effector components in combating the pathogen, and is able to target adaptive immunity. Several cells of the immune system are activated through their cell receptors to generate an antigenic response, such as Natural Killer cells, lymphocytes, among others. Among the receptors expressed by Natural Killer cells, the Toll-Like receptors (TLR) on the surface and cellular cytoplasm stand out in the innate immune response [6] [7].

Each member of the TLR family is activated by specific antigens that lead to different transcriptional activation profiles, initiating an appropriate immune response to the pathogen. These receptors recognize lipoproteins present in the bacillus and promote the differentiation of monocytes into macrophages and $\mathrm{CD} 1 \mathrm{~b}+$ dendritic cells, which in turn activate lymphocytes that release cytokines such as TNF- $\alpha$ and IL-12, promoting antimicrobial activity. Of all mammalian TLRs, TLR2 is the one that detects the broadest repertoire of molecular patterns in a wide variety of pathogens, including mycobacteria, which makes it of particular clinical importance [8] [9].

Because $M$. leprae, in the host, initiates cell signaling by activating the TLR1/TLR2 heterodimer, changes in these genes may be able to confer susceptibility to leprosy [8]. Thus, a study involving the detection of SNPs 2029 (rs121917864; exchange of cytokine to thymine) and 2258 (rs137853176; exchange of guanine to adenine) in the TLR2 gene in leprosy patients and their healthy contacts, relating to the immune response may elucidate important aspects susceptibility of individuals to leprosy.

Thus, this study aimed to verify the relationship between SNPs 2029 and 2258 of the TLR-2 gene and leprosy, describing and comparing the genotypes and alleles in leprosy cases and their healthy contacts.

\section{Materials and Methods}

The study included individuals from the municipality of Redenção and Altamira, 
located in the State of Pará-Brazil, who agreed to participate in this study and signed a consent form according to Resolution No. 466 of the National Health Council. This study was approved by the Ethics and Research Committee of the Evandro Chagas Institute with the report number: 2.364.234. Individuals who did not sign the consent form and individuals with some immunodeficiency were excluded.

Individuals with a clinical diagnosis of leprosy, undergoing treatment or who ended treatment, were designated as a group of patients, who at the time of diagnosis were classified according to the Ministry of Health into paucibacillary (PB) or multibacillary (MB). Thus, 45 patients were included, $34 \mathrm{MB}$ and $11 \mathrm{~PB}$ and a group of 82 contact persons who live with the patient (household) and do not present clinical symptoms of leprosy.

In February 2018, blood samples were collected from the participants, at the municipal health centers, by venipuncture in $5 \mathrm{ml}$ tubes, and stocked at $-20^{\circ} \mathrm{C}$ for subsequent laboratory procedures.

DNA extractions were performed at the Evandro Chagas Institute, Bacteriology and Mycology Section, Molecular Biology Laboratory, using the DNeasy Blood \& Tissue kit (QIAGEN), following the manufacturer's instructions.

In order to classify polymorphisms, a $736 \mathrm{bp}$ fragment was amplified through beginner nucleotides for PCR (Forward: 5'CTGTGCTCTGTTCCTGCTGA3' and Reverse: 5'AAACAGCACCCCAGACAAAA3'), developed by the Primer3Plus program from the genomic region "Homo sapiens toll like receptor 2 (TLR2), transcription variant X6, mRNA", deposited on GenBank with a reference XM_011532216.2.

The amplified products were submitted to the ABI 3130 Genetic Analyzer (Applied Biosystems $s^{\circledast}$ ) sequencer with posterior BLAST on the National Center for Biotechnology Information (NCBI) website

(https://blast.ncbi.nlm.nih.gov/Blast.cgi). The results were organized in a database of the epi info ${ }^{t m} 7$ program. The observed presence proportions of the polymorphism within each group studied were analyzed using Fisher's exact test.

\section{Results}

In this study, the genotypes of 127 individuals were typified, being 82 individuals household contacts of patients, $34 \mathrm{MB}$ and $11 \mathrm{~PB}$. Of the 127 individuals analyzed, 78 were female and 49 male, with most of the contacts being female (64.5\%), the majority of MB male (56\%) and almost all PB female gender (91\%) (Table 1).

Regarding the age group, most contacts and individuals in the PB group were 32 to 46 years old and most individuals in the MB group were older than 46 years (39\%, 54.5\% and $42 \%$ and respectively) (Table 2 ).

As for the distribution of the SNP 2029 genotypes of the TLR2 gene between the groups, it was observed that all $\mathrm{MB}$ individuals had the $\mathrm{C} / \mathrm{C}$ genotype and the mutant genotype, $\mathrm{C} / \mathrm{T}$, was observed only in contacts and paucibacillaries $(\mathrm{N}$ 
$=5$ and 1 , respectively; Table 3 ).

Regarding the distribution of the frequency of alleles for SNP 2029 between the groups, it was observed that all $\mathrm{MB}$ individuals presented only $\mathrm{C}$ allele and the mutant $(\mathrm{T})$ allele was observed only in contacts and paucibacillaries (3\%, $4.5 \%$, respectively) (Table 4 ).

Table 1. Distribution of gender in the studied groups.

\begin{tabular}{cccc}
\hline Gender & Contact N (\%) & MB N (\%) & PB N (\%) \\
\hline Female & $53(64.5)$ & $15(44)$ & $10(91)$ \\
Male & $29(35.5)$ & $19(56)$ & $1(9)$ \\
Total & 82 & 34 & 11 \\
\hline
\end{tabular}

MB: Multibacillary; PB: Paucibacilar; $\mathrm{P}<0.05$, Fisher's exact test.

Table 2. Age group distribution in the studied groups.

\begin{tabular}{cccc}
\hline Age Group (years) & Contact N (\%) & MB N (\%) & PB N (\%) \\
\hline$>46$ & $22(27)$ & $19(56)$ & $4(36.5)$ \\
$0-15$ & $12(14.5)$ & $1(3)$ & $0(0)$ \\
$16-31$ & $16(19.5)$ & $2(6)$ & $1(9)$ \\
$32-46$ & $32(39)$ & $12(35)$ & $6(54.5)$ \\
Total & 82 & 34 & 11 \\
\hline
\end{tabular}

MB: Multibacillary; PB: Paucibacilar; $\mathrm{P}<0.05$, Fisher's exact test.

Table 3. Distribution of genotypes and alleles in groups for SNP 2029.

\begin{tabular}{cccc}
\hline Genotypes & Contact N (\%) & MB N (\%) & PB N (\%) \\
\hline C/C & $77(94)$ & $34(100)$ & $10(95.7)$ \\
C/T & $5(6)$ & $0(0)$ & $1(4.3)$ \\
Total & 82 & 34 & 11 \\
Alleles & $159(97)$ & $68(100)$ & $21(95.5)$ \\
C & $5(3)$ & 0 & $1(4.5)$ \\
T & 164 & 62 & 22 \\
Total & & & \\
\hline
\end{tabular}

MB: Multibacillary; PB: Paucibacilar; $\mathrm{P}<0.05$, Fisher's exact test.

Table 4. Distribution of genotypes and alleles in groups for SNP 2258.

\begin{tabular}{cccc}
\hline Gentypes & Contact N (\%) & MB N (\%) & PB N (\%) \\
\hline G/A & $3(3.6)$ & 0 & $1(9)$ \\
G/G & $79(96.4)$ & $34(100)$ & $10(91)$ \\
Total & 82 & 34 & 11 \\
Alleles & $3(2)$ & 0 & $1(4.5)$ \\
A & $161(98)$ & $68(100)$ & $21(95.5)$ \\
G & 164 & 68 & 22 \\
Total & & &
\end{tabular}

MB: Multibacillary; PB: Paucibacilar; $\mathrm{P}<0.05$, Fisher's exact test. 
In the analysis of the distribution of the SNP 2258 genotypes of the TLR-2 gene between the groups, it was observed that of the 82 typified contacts, 79 had G/G genotype and only 3 had G/A genotype, the MB group had only the G genotype./G and the PB group was predominant $\mathrm{G} / \mathrm{G}$ (91\%), presenting only 1 G/A genotype (Table 4).

\section{Discussion}

Despite advances in research, diagnosis and the establishment of a free and effective therapy, leprosy is still endemic in Brazil and other developing countries. There have been many efforts by public agencies to eradicate the infection; however, in Brazil the disease still has active foci of transmission [10].

In recent years, several researches have been carried out in the field of molecular biology in order to ascertain the immunogenetic profile of the host against infections caused by mycobacteria, mainly due to the particularities regarding genes related to the cellular immune response Th1/Th2, in order to identify genetic components that may provide the opportunity for the infection to install in the host organism. Today, some sets of genes have been linked to leprosy susceptibility and resistance [11].

The immune response to leprosy depends on a cascade of factors ranging from the recognition of the pathogen by specific receptors that trigger the synthesis of important cytokines to the activation of macrophages and differentiation of Th1 cells. The Virchovian form is characterized by a deficiency in the differentiation of Th1 lymphocytes and consequently excessive multiplication of bacilli. TLR-2 is important in the response against mycobacteria and according to studies carried out with different populations worldwide, polymorphisms in the TLR-2 gene may be associated with deficiency in the immune response and, consequently, with susceptibility to mycobacterioses [12] [13].

The various studies that analyzed possible associations of SNPs in toll-like receptors with susceptibility to infections caused by mycobacteria showed divergent results from one population to another. According to some researchers, this may be a consequence of the genetic background of populations in studies so far [14] [15] [16]. The genetic background is the framework of genes of each individual, this set of genes can vary over the years and also with the environment actions in which it is inserted [17] [18] [19].

TLR-2 is located on chromosome $4 \mathrm{q} 32$, is composed of 3 exons, two coding and one non-coding. One of the known polymorphisms of this gene is in position 2029 (rs121917864) and is characterized by the exchange of a cytosine for a thymine $(\mathrm{C} / \mathrm{T})$, this results in the exchange of the amino acid arginine for a tryptophan, in position 677 [20]. When there is no mutation (C/C genotype), IL-12 levels are higher than IL-10 levels, however in the presence of the mutation (C/T and T/T genotypes) the opposite happens. IL-10 is a macrophage-suppressing cytokine found in greater quantities in patients with HV, while IL-12 stimulates the production of IFN- $\gamma$, induces Th differentiation to become Th1 and is found in 
greater quantities in HT patients [4] [5].

In a study conducted with a Korean population of $45 \mathrm{HV}$ patients, $41 \mathrm{HT}$ and 45 controls, the mutation was identified only in HV patients, which led the authors to suggest the association of the $\mathrm{T}$ allele with the severe form of the disease [21] [22]. Contrary results were observed in the present study, since the $\mathrm{T}$ allele was not observed in any of the $34 \mathrm{HV}$ patients, being quite rare in the population of this study, found only in 6 individuals with heterozygous genotype $(\mathrm{C} / \mathrm{T})$, being in $1 \mathrm{HT}$ and in 5 healthy contacts. Thus, in this study, we observed a greater similarity between the PB and contact groups, in which the mutation was very rare and could be protective against leprosy and or its aggravated form.

Despite what was shown in the Korean population by Kang et al. [21] and observed in the present study, Malhotra et al. [22] did not identify polymorphism at position 2029 in an Indian population and Mikita et al. [23] did not identify in Japanese leprosy patients. However, these different results can be explained by the different genetic origins among different populations.

Pioneering study by Lorenz et al. [24] reported a new polymorphism in the TLR2 gene, the exchange of a guanine for an adenine at position SNP 2258 (rs137853176), leading to the substitution of arginine for glutamine in residue 753 that causes a reduced macrophage response to bacterial peptides, resulting in an attenuated immune response in the host. Studies carried out to identify the frequency of SNP 2258 in 4 different populations (Americans from Utah, USA descended from Europeans; Chinese from Beijing; Japanese from Tokyo and Nigerians from Ibadan), published in HapMap [25] demonstrated that the A allele was considered rare and/or absent in these populations.

In a study carried out with the Amazonian population, by Naveca [26], for a possible association with susceptibility to TB, the A allele of SNP 2258, was absent in the individuals analyzed and not associated with the disease. A study by Sanchez et al. [16] in a population in Colombia also demonstrated the A allele as rare in patients and controls, $(0.64 \%$ and $1.33 \%$, respectively), and thus also not relevant to the risk of TB in this population involved.

However, Ogus et al. [27] observed the A allele in $17.9 \%$ and $7.7 \%$ of patients and controls, respectively. When the reasons for the three genotypes were compared between the two groups, the A/A genotype proved to be more significantly associated with TB. The risk of developing TB was increased by 6.04 and 1.60 times for patients with genotypes A/A and G/A, respectively. Therefore, these data suggest that the substitution of arginine for glutamine at position 753 of the TLR2 gene influences the risk of developing tuberculosis.

In the present study, during an analysis of the distribution of the SNP 2258 genotypes of the TLR2 gene, the predominance among the population of the G/G genotype (96.4\%) was detected, with allele A being found in one of the PB and three contacts and not found in $\mathrm{MB}$, ratifying what was found in studies carried out on other populations and contributing information that the A allele is rare. Thus, in this study, we observed a greater similarity between the PB and 
contact groups, in which the mutation was very rare and could be protective against leprosy or its aggravated form.

In addition to the similarity observed between the PB and contacts groups in relation to the SNPs studied (although without statistical significance), a similarity was also observed in relation to the age group and sex (statistically significant), as these two groups are predominantly female with age group from 32 to 46 years old, while MB is the majority male with age group above 46 years old. These data corroborate with other studies carried out by Bakker et al. [28] and Lima et al. [29].

\section{Conclusion}

To date, the results of this research do not indicate associations of SNPs 2029 and 2258 of the TLR2 gene and protection or susceptibility to leprosy, demonstrating that the sequences covering these regions are well conserved in the study population. Thus, due to the low frequency in the incidence of the SNPs studied in the investigated population, it is necessary to intensify the studies, in addition to investigating other regions of the genome that aim to clarify the involvement of TLR and the immune response triggered in the face of host-pathogen contact.

\section{Ethical Clearance}

This study was approved by the Ethics and Research Committee of the Instituto Evandro Chagas with the report number: 2.364.234.

\section{Authors Contributions}

The table below indicates the contributions of all named authors.

\begin{tabular}{|c|c|c|c|c|c|}
\hline \multirow[b]{2}{*}{ Author's initials } & \multicolumn{5}{|c|}{ Type of contribution } \\
\hline & $\begin{array}{l}\text { Study } \\
\text { design }\end{array}$ & $\begin{array}{l}\text { Study } \\
\text { implementation }\end{array}$ & $\begin{array}{l}\text { Analysis and } \\
\text { interpretation } \\
\text { of data }\end{array}$ & $\begin{array}{l}\text { Major } \\
\text { contribution } \\
\text { to writing }\end{array}$ & $\begin{array}{l}\text { Read and } \\
\text { approved } \\
\text { final version }\end{array}$ \\
\hline $\begin{array}{l}\text { Luana Nepomuceno } \\
\text { Gondim Costa Lima }\end{array}$ & $\mathrm{X}$ & $\mathrm{X}$ & $\mathrm{X}$ & $\mathrm{X}$ & $\mathrm{X}$ \\
\hline Letícia Siqueira Moura & & $\mathrm{X}$ & $\mathrm{X}$ & $\mathrm{X}$ & $\mathrm{X}$ \\
\hline Jasna Leticia Pinto Paz & & $\mathrm{X}$ & $\mathrm{X}$ & & $\mathrm{X}$ \\
\hline $\begin{array}{l}\text { Maria do Perpétuo } \\
\text { Socorro Amador Silvestre }\end{array}$ & & $\mathrm{X}$ & & & $\mathrm{X}$ \\
\hline Daniele Melo Sardinha & & & $\mathrm{X}$ & & $\mathrm{X}$ \\
\hline Letícia Diogo de Oliveira & & & $\mathrm{X}$ & & $\mathrm{X}$ \\
\hline Karla Valéria Batista Lima & & & $\mathrm{X}$ & $\mathrm{X}$ & $\mathrm{X}$ \\
\hline
\end{tabular}

\section{Conflicts of Interest}

The authors declare no conflicts of interest regarding the publication of this paper. 


\section{References}

[1] Jin, S.-H., Ahn, K.J. and An, S. (2018) Importance of the Immune Response to $M y^{-}$ cobacterium leprae in the Skin. Biomedical Dermatology, 2, Article No. 1. https://doi.org/10.1186/s41702-017-0012-5

[2] Ribeiro, M.D., Silva, J.C. and Oliveira, S. (2018) Estudo epidemiológico da hanseníase no Brasil: Reflexão sobre as metas de eliminação. Revista Panamericana de Salud Publica, 42, 1-7. https://doi.org/10.26633/RPSP.2018.42

[3] White, C. and Franco-Paredes, C. (2015) Leprosy in the 21st Century. Clinical Microbiology Reviews, 28, 80-94. https://doi.org/10.1128/CMR.00079-13

[4] Sauer, M.E.D., Salomão, H., Ramos, G.B., D’Espindula, H.R.S., Rodrigues, R.S.A., Macedo, W.C., et al. (2015) Genetics of Leprosy: Expected and Unexpected Developments and Perspectives. Clinics in Dermatology, 33, 99-107. https://doi.org/10.1016/j.clindermatol.2014.10.001

[5] Mory, D.B., Gabbay, M.A.L., Rocco, E.R., Kasamatsu, T., Crispim, F., Miranda, W.L., et al. (2016) High Frequency of Vitamin D Receptor Gene Polymorphism FokI in Brazilian Type 1 Diabetes Mellitus Patients with Clinical Autoimmune Thyroid Disease. Diabetology \& Metabolic Syndrome, 8, 29. https://doi.org/10.1186/s13098-016-0145-5

[6] Fonseca, A.B.L., Simon, M.V., Cazzaniga, R.A., de Moura, T.R., de Almeida, R.P., Duthie, M.S., et al. (2017) The Influence of Innate and Adaptive Immune Responses on the Differential Clinical Outcomes of Leprosy. Infectious Diseases of Poverty, 6 , 5. https://doi.org/10.1186/s40249-016-0229-3

[7] Pinheiro, R.O., Schmitz, V., Silva, B.J.A., Dias, A.A., de Souza, B.J., de Mattos Barbosa, M.G., et al. (2018) Innate Immune Responses in Leprosy. Frontiers in Immunology, 9, 518. https://doi.org/10.3389/fimmu.2018.00518

[8] Santana, N.L., Rêgo, J.L., Oliveira, J.M., Almeida, L.F., Braz, M., Machado, L.M.M., et al. (2017) Polymorphisms in Genes TLR1, 2 and 4 Are Associated with Differential Cytokine and Chemokine Serum Production in Patients with Leprosy. Memórias do Instituto Oswaldo Cruz, 112, 260-268.

https://doi.org/10.1590/0074-02760160366

[9] Bolz, M. and Ernst, J.D. (2017) Fishing for Answers in Human Mycobacterial Infections. Immunity, 47, 395-397. https://doi.org/10.1016/j.immuni.2017.09.005

[10] Souza, E.A., Ferreira, A.F., Boigny, R.N., Alencar, C.H., Heukelbach, J., Martins-Melo, F.R., et al. (2018) Leprosy and Gender in Brazil: Trends in an Endemic Area of the Northeast Region, 2001-2014. Revista de Saude Publica, 52, 20. https://doi.org/10.11606/S1518-8787.2018052000335

[11] Prevedello, F.C. and Mira, M.T. (2007) Hanseníase: Uma doença genética? Anais Brasileiros de Dermatologia, 82, 451-459. https://doi.org/10.1590/S0365-05962007000500009

[12] Casanova, J.-L., Abel, L. and Quintana-Murci, L. (2011) Human TLRs and IL-1Rs in Host Defense: Natural Insights from Evolutionary, Epidemiological, and Clinical Genetics. Annual Review of Immunology, 29, 447-491. https://doi.org/10.1146/annurev-immunol-030409-101335

[13] Zhang, H., Li, D., Zhao, L., Fleming, J., Lin, N., Wang, T., et al. (2013) Genome Sequencing of 161 Mycobacterium tuberculosis Isolates from China Identifies Genes and Intergenic Regions Associated with Drug Resistance. Nature Genetics, 45, 1255-1260. https://doi.org/10.1038/ng.2735

[14] Van der Graaf, C., Kullberg, B.J., Joosten, L., Verver-Jansen, T., Jacobs, L., Van der Meer, J.W.M., et al. (2005) Functional Consequences of the Asp299Gly Toll-Like 
Receptor-4 Polymorphism. Cytokine, 30, 264-268. https://doi.org/10.1016/j.cyto.2005.02.001

[15] Ma, M., Xie, L., Wu, S., Tang, F., Li, H., Zhang, Z., et al. (2010) Toll-Like Receptors, Tumor Necrosis Factor- $\alpha$, and Interleukin-10 Gene Polymorphisms in Risk of Pulmonary Tuberculosis and Disease Severity. Human Immunology, 71, 1005-1010. https://doi.org/10.1016/j.humimm.2010.07.009

[16] Sánchez, D., Lefebvre, C., Rioux, J., García, L.F. and Barrera, L.F. (2012) Evaluation of Toll-Like Receptor and Adaptor Molecule Polymorphisms for Susceptibility to Tuberculosis in a Colombian Population. International Journal of Immunogenetics, 39, 216-223. https://doi.org/10.1111/j.1744-313X.2011.01077.x

[17] Sigmund, C.D. (2000) Viewpoint: Are Studies in Genetically Altered Mice Out of Control? Arteriosclerosis, Thrombosis, and Vascular Biology, 20, 1425-1429. https://doi.org/10.1161/01.ATV.20.6.1425

[18] Johnson, K.R., Zheng, Q.Y. and Noben-Trauth, K. (2006) Strain Background Effects and Genetic Modifiers of Hearing in Mice. Brain Research, 1091, 79-88. https://doi.org/10.1016/j.brainres.2006.02.021

[19] Doetschman, T. (2009) Influence of Genetic Background on Genetically Engineered Mouse Phenotypes. Methods in Molecular Biology, 530, 423-433. https://doi.org/10.1007/978-1-59745-471-1_23

[20] Texereau, J., Chiche, J.-D., Taylor, W., Choukroun, G., Comba, B. and Mira, J.-P. (2005) The Importance of Toll-Like Receptor 2 Polymorphisms in Severe Infections. Clinical Infectious Diseases, 41, S408-S415. https://doi.org/10.1086/431990

[21] Kang, T.J. and Chae, G.T. (2001) Detection of Toll-Like Receptor 2 (TLR2) Mutation in the Lepromatous Leprosy Patients. FEMS Immunology and Medical Microbiology, 31, 53-58. https://doi.org/10.1111/j.1574-695X.2001.tb01586.x

[22] Malhotra, D., Relhan, V., Reddy, B.S.N. and Bamezai, R. (2005) TLR2 Arg677Trp Polymorphism in Leprosy: Revisited. Human Genetics, 116, 413-415. https://doi.org/10.1007/s00439-004-1249-9

[23] Mikita, N., Kanazawa, N., Ozaki, M., Kosaka, M., Ishii, N., Nishimura, H., et al. (2009) No Involvement of Non-Synonymous TLR2 Polymorphisms in Japanese Leprosy Patients. Journal of Dermatological Science, 54, 48-49. https://doi.org/10.1016/j.jdermsci.2008.11.001

[24] Lorenz, E., Mira, J.P., Cornish, K.L., Arbour, N.C. and Schwartz, D.A. (2000) A Novel Polymorphism in the Toll-Like Receptor 2 Gene and Its Potential Association with Staphylococcal Infection. Infection and Immunity, 68, 6398-6401. https://doi.org/10.1128/IAI.68.11.6398-6401.2000

[25] HapMap. (n.d.) The International HapMap Project. Probe (Lond). https://www.ncbi.nlm.nih.gov/probe/docs/projhapmap

[26] Naveca, R.H.B. (2014) Influência De Polimorfismos Dos Genes Tlr (Toll-Like Receptors) Sobre a Tuberculose em uma população da amazônia. Instituto Nacional de Pesquisas da Amazônia INPA.

[27] Ogus, A.C., Yoldas, B., Ozdemir, T., Uguz, A., Olcen, S., Keser, I., et al. (2004) The Arg753Gln Polymorphism of the Human Toll-Like Receptor 2 Gene in Tuberculosis Disease. European Respiratory Journal, 23, 219-223. https://doi.org/10.1183/09031936.03.00061703

[28] Bakker, M.I., Hatta, M., Kwenang, A., Van Mosseveld, P., Faber, W.R., Klatser, P.R., et al. (2006) Risk Factors for Developing Leprosy-A Population-Based Cohort Study in Indonesia. Leprosy Review, 77, 48-61. 
[29] Lima, L.N.G.C., Frota, C.C., Mota, R.M.S., Almeida, R.L.F., Pontes, M.A.A., Gonçalves, H.S., et al. (2015) Widespread Nasal Carriage of Mycobacterium lepraeamong a Healthy Population in a Hyperendemic Region of Northeastern Brazil. Memórias do Instituto Oswaldo Cruz, 110, 898-905.

https://doi.org/10.1590/0074-02760150178 